\title{
ANALISIS FAKTOR-FAKTOR YANG MEMPENGARUHI KUALITAS INFORMASI AKUNTANSI PADA ORGANISASI PERANGKAT DAERAH (OPD) DI GUNUNGKIDUL
}

\author{
Putri Utami, Vidya Vitta Adhivinna \\ Universitas PGRI Yogyakarta \\ J1. PGRI 1 Sonosewu No. 117, Yogyakarta \\ putami687@gmail.com, adhivinna@upy.ac.id
}

\begin{abstract}
Accounting information is very important thing in business activities or government. Accounting information is used as decision making in organization. The purpose this research to analyze affect relevant information, reliable information, complete information, timely information, understandable information toward quality accounting information at Organisasi Perangkat Daerah (OPD) in Gunungkidul.

This Research is quantitative research with purposive random sampling technique. Employee population 11 Dinas that use Accounting Information, the sample of wich was obtained 68 people. The analysis technique used is multiple regression analysis.

The result of the research shows that partially relevant information valuable 0,000 and complete information valuable 0,000 smaller than 0,05 has an effect on quality accounting information, while reliable information valuable 0,351 , timely information valuable 0,574 and understandable information valuable 0,680 greather than 0,05 no effect on quality accounting information. But simultaneously relevant information, reliable information, timely information, complete information and understandable information affect the performance of accounting information valuable 0,000 greather 0,05.
\end{abstract}

Keywords: relevant information, reliable information, complete information, timely information, understandable information, quality accounting information.

\section{PENDAHULUAN}

Informasi merupakan sumber daya yang sangat bernilai bagi sebuah organisasi dalam setiap transaksi, karena proses kegiatan mampu berjalan dengan efektif dan efisien dengan dukungan informasi yang baik. Perkembangan organisasi pemerintah yang semakin kompleks menyebabkan ketergantungan manusia terhadap informasi yang semakin bertambah (Agustina dan Nur, 2015).

Informasi akuntansi merupakan hal yang vital dalam kegiatan bisnis ataupun pemerintahan. Informasi akuntansi digunakan sebagai pengambil keputusan didalam organisasi (atasan, dan orang yang konsen terlibat dalam organisasi), 
digunakan sebagai pengambil keputusan diluar organisasi, maupun kreditor.

Menurut Bodnar dan Hopwood (2003) kualitas informasi merupakan tingkat dari sebuah data yang telah diproses oleh sistem informasi menjadi memiliki arti bagi penggunanya, yang bisa berupa fakta dan suatu nilai yang bermanfaat. Data merupakan input bagi sebuah informasi, sedangkan informasi adalah output yang dihasilkan. Perbedaan antara data dan informasi, data adalah berbagai fakta yang akan atau mungkin tidak diproses (diedit, diringkas dan diperbaiki) dan tidak memiliki pengaruh langsung atas pengguna, sedangkan informasi menyebabkan pengguna mengambil tindakan yang akan dilakukan atau tidak dilakukan, karena dikatakan sebagai sebagai informasi ditentukan berdasarkan pengaruhnya terhadap penggunannya bukan terhadap bentuk fisiknya (Hall, 2004).

Undang-undang No. 23 tahun 2004 tentang Perangkat Daerah pembentukan Satuan Kerja Perangkat Daerah (SKPD) telah diperbarui dengan adanya Peraturan Pemerintah No. 16 Tahun 2016 tentang Perangkat Daerah dan menggantinya dengan Organisasi Perangkat Daerah (OPD). Adanya perubahan peraturan tersebut membuat Kabupaten Gunungkidul membuat Peraturan Daerah No. 7 tahun 2016 tentang pembentukan dan susunan perangkat daerah Kabupaten Gunungkidul.Organisasi Perangkat Daerah (OPD) merupakan pelaksana fungsi eksekutif yang harus berkoordinasi agar penyelenggaraan pemerintahan berjalan dengan baik. OPD dibagi menjadi dua yaitu, pemerintah daerah Provinsi dan pemerintah daerah Kabupaten/ Kota.

Proses akuntansi atau tata keuangan telah mengalami perkembagan seiring dengan adanya Undang-Undang Nomor 17 Tahun 2003 tentang Keuangan Negara yang mensyaratkan bentuk dan isi laporan keuangan. Institusi-institusi pemerintahan saat ini, harus semakin memperbaiki kualitas kinerja keuangan agar mampu mengikuti perkembangan akuntansi karena pengguna informasi terutama masyarakat umum menuntut peningkatan akuntabilitas dan transparansi di institusi-institusi pemerintahan. Pemerintah daerah mempunyai kewajiban mempublikasikan informasi melalui laporan keuangan yang digunakan sebagai dasar pengambilan keputusan. Publikasi informasi tersebut dapat digunakan untuk kepentingan-kepentingan para pemakai informasi (Andriani, 2010).

Penelitian Aditya (2014) dan Rusnanto (2014) menunjukan bahwa peningkatan kualitas informasi akuntansi dapat meningkatkan strategi dan mempengaruhi pengambilan keputusan yang tepat dan mewujudkan tujuan organsasi pada Rumah Sakit Daerah Ungaran dan PKU Muhammadiyah EksKarisidenan Surakarta.Menurut Romney (2006) karakteristik informasi yang berkualitas adalah, informasi yang relevan, terpercaya, lengkap, tepat waktu dan dimengerti.Berdasarkan uraian diatas penulis tertarik untuk melakukan penelitian tentang kualitas informasi akuntansi pada Organisasi Perangkat Daerah di Kabupaten Gunungkidul. 
Persamaan dan perbedaan penelitian ini dengan penelitian terdahulu adalah:

1. Persamaan Peneltian

a. Sama-sama meneliti tentang kualitas informasi akuntansi

b. Metode pengumpulan data menggunakan kuesioner dan pengukurannya dengan skala likert,

2. Perbedaan Penelitian

a. Penelitian Rusnanto (2016) meneliti pada

\section{TINJAUAN PUSTAKA Dasar Teori}

\section{Kualitas Informasi Akuntansi}

Kualitas informasi adalah kualitas keluaran (output)informasi yang diberikan oleh sistem. Atkinson et. all, dalam Widarsono (2007), menjelaskan bahwa informasi yang dihasilkan dari sistem informasi dapat digunakan untuk mengukur kinerja ekonomi dari unit organisasi dalam perusahaan.

Informasi yang digunakan untuk pengambilan keputusan oleh manajer harus informasi yang memiliki kualitas atau karakteristik informasi yang baik sehingga pengambilan keputusan tepat dan pada akhirnya dapat meningkatkan kinerja secara keseluruhan. Romney et al, (2006) menyatakan indikasi dari kualitas informasi akuntansi adalah mengurangi ketidakpastian, mendukung keputusan, mendorong untuk lebih baik dalam hal perencanaan aktivitas kerja. Kualitas informasi akuntansi dapat diukur

$\begin{array}{lr}\begin{array}{lr}\text { Rumah Sakit } \\ \text { Muhammadiyah }\end{array} & \text { Eks- } \\ \text { Karisidenan Surakarta } & \text { Suran } \\ \text { dan Aditya } & (2014) \\ \text { melakukan penelitian } & \\ \text { pada Rumah Sakit Umum } & \\ \text { Daerah di Unggaran. }\end{array}$

Berdasarkan uraian diatas penulis tertarik untuk melakukan penelitian tentang kualitas informasi akuntansi pada Organisasi Perangkat Daerah (OPD) di Kabupaten Gunungkidul. dengan kepuasan pengguna informasi akuntansi.

Menurut Mulyanto (2009) Parameter untuk mengukur nilai informasi (value of information) ditentukan dari manfaat (benefit) dan biaya (cost), tetapi pada kenyataannya informasi dengan biaya tinggi belum tentu memiliki manfaat yang tinggi. Sebuah informasi dikatakan bernilai apabila manfaatnya lebih efektif dibanding dengan biaya untuk mendapatkanya dan sebagian informasi tidak dapat ditaksir dengan keuntungannya dengan satuan nilai uang, tetapi dapat ditaksir dengan nilai efektivitasnya.

\section{Informasi yang relevan}

Menurut Krismiaji (2002) informasi akuntansi yang relevan dapat menambah pengetahuan atau nilai bagi para pengambil keputusan untuk mengurangi ketidakpastian, menaikan kemampuan untuk memprediksi, menegaskan atau 
membenarkan espektasi semula. Informasi memiliki kualitas relevan apabila dapat mempengaruhi keputusan ekonomi pemakai dengan membantu mereka mengevaluasi peristiwa masa lalu, masa kini atau masa depan, menegaskan, atau mengkoreksi hasil evaluasi mereka di masa lalu.

\section{Informasi yang terpercaya} Romney et. all dalam Widarsono (2007), berpendapat bahwa informasi dikatakan terpercaya bila dia bebas dari kesalahan dan bias, serta secara akurat menjelaskan kejadian atau aktivitas organisasi.sumber informasi harus dapat dipercaya; artinya, informasi tersebut diperoleh dengan cara dan dari sumber yang tepat, kemudian diproses dengan cara yang benar, dan didistribusikan dengan cara yang juga dapat dipercaya.

4. Informasi yang lengkap Informasi dikatakan lengkap atau utuh bila tidak meninggalkan aspek- aspek penting yang melatarbelakangi setiap butir informasi utama yang termuat dalam

\section{METODOLOGI PENELITIAN}

\section{Variabel Penelitian}

Penelitian in menggunakan 2 variabel, yaitu variabel independen dan variabel dependen.Variabel independen dalam penelitian ini adalah informasi yang relevan, terpercaya, lengkap, tepat waktu, dimengerti, sedangkan variabel dependen dalam penelitian ini adalah kualitas informasi akuntansi.

\section{Populasi dan Sampel}

Populasi yang digunakan daldfetod penelitian ini adalah karyawan/ pegawai 11 Instansi Organisasi Perangkat Daerah (OPD) di Gunungkidul.

Teknik penhgambilan sampel penelitian ini adalah purposive sampling .Sampel penelitian ini adalah bagian administrasi umum dan keuangan sebanyak 68 orang. laporan keuangan diungkapkan dengan jelas agar kekeliruan dalam penggunaan informasi tersebut dapat dicegah (Romney, 2006 ).Informasi yang lengkap harus memenuhi kualitas dan kuantitas sesuai dan memenuhi kebutuhan pemakai informasi sehingga pemakai dapat mendapatkan informasi yang mereka cari.

\section{Informasi yang tepat waktu} Menurut Aditya (2014) Informasi dikatakan tepat waktu apabila informasi tersedia pada waktu para pengambil keputusan menggunakannya untuk membuat keputusan.Ketepatan waktu memiliki dua segi yang berkaitan yaitu: frekuensi dan hambatan. Frekuensi menunjukan seberapa sering informasi dimutakhirkan dan diukur selama interval waktu antara dua laporan berturut-turut untuk informasi yang serupa. Keterlambatan (delay) adalah lamanya waktu yang berlalu setelah suatu peristiwa terjadi sampai informasi yang bersangkutan sampai pada pemakai.

\section{Metode Pengumpulan Data}

Metode yang digunakan dalam pengumpulan data penelitian ini adalah metode purposive, dimana data peneltian disebarkan dengan kuesioner yang diserahkan kepada 11 Instansi Oeganisasi Perangkat Daerah (OPD) di Gunungkidul.

\section{Metode Analisis Data}

Analisis data dilakukan dengan menggunakan bantuan program SPSS for Windows 16.00. Kegiatan dalam analisis data adalah mengkelompokan data berdasarkan variabel dan jenis responden, menyajikan data tiap variabel yang diteliti, melakukan perhitungan 
untuk menjawab rumusan masalah dan melakukan perhitungan untuk menguji hipotesis yang telah diajukan (Sugiyono, 2016).

\section{Uji Kualitas Data}

Uji Validitas dalam penelitian ini dilakukan dengan menggunakan Pearson Correlation yaitu dengan menghitung korelasi antara skor masing- masing butir pertanyaan dengan total skor. Uji reliablitas dilakukan dengan melihat hasil dari Cronbach Alpha Coefficient. Suatu instrumen dikatakan reliabel bila memiliki koefisien keandalan reliabilitas sebesar 0,6 atau lebih.

\section{Uji Hipotesis}

Uji hipotesis dalam penelitian ini menggunakan Uji Regresi Linear berganda meliputi: a. Uji t (parsial)

b. Uji F (Simultan)

c. $\mathrm{R}^{2} \quad$ (Koefisien Determinasi)

Rumus Persamaan Uji regresi linear berganda adalah:

$Y=\alpha+\beta_{1} X_{1}+\beta_{2} X_{2}+\beta_{3} X_{3}+\beta_{4} X_{4}+$ $\beta_{5} \mathrm{X}_{5}+\varepsilon$

Keterangan:

$\alpha=$ Konstana

$\mathrm{Y}=$ Kualitas Informasi Akuntan

si

$\mathrm{X}_{1} \quad=$ Informasi yang relevan

$\mathrm{X}_{2} \quad$ = Informasi yang terpercaya

$\mathrm{X}_{3} \quad=$ Informasi yang lengkap

$\mathrm{X}_{4} \quad=$ Informasi yang tepat waktu

$\mathrm{X}_{5} \quad=$ Informasi yang dimengerti

$\varepsilon \quad=$ Error

\section{HASIL PENELITIAN DAN PEMBAHASAN}

\section{Data Penelitian}

Responden penelitian ini adalah 68 Perangkat Daerah (OPD) di karyawan bagian administrasi umum dan Gunungkidul.Berikut ini adalah hasil keuangan pada 11 Instansi organisasi distribusi penyebaran kuesioner:

Tabel 1 Data Instansi/ Dinas

\begin{tabular}{|c|l|c|c|}
\hline \multirow{2}{*}{ No } & \multicolumn{1}{|c|}{ Instansi } & \multicolumn{2}{|c|}{ Responden } \\
\cline { 3 - 4 } & & Adm. Umum & Keuangan \\
\hline 1. & $\begin{array}{l}\text { Dinas Pendidikan Pemuda } \\
\text { dan Olahraga }\end{array}$ & 2 & 3 \\
\hline 2. & Dinas Pariwisata & 1 & 5 \\
\hline 3. & $\begin{array}{l}\text { Dinas Pendapatan, Pengelo } \\
\text { laan Keuangan dan Aset D } \\
\text { aerah }\end{array}$ & 1 & 5 \\
\hline 4. & $\begin{array}{l}\text { Dinas Tenaga Kerja dan Tr } \\
\text { ansmigrasi }\end{array}$ & 2 & 4 \\
\hline 5. & Dinas Perhubungan & 1 & 5 \\
\hline 6. & Dinas Pekerjaan Umum & 2 & 3 \\
\hline 7. & $\begin{array}{l}\text { Dinas Pertanian dan Ketah } \\
\text { anan Pangan }\end{array}$ & 1 & 5 \\
\hline 8. & Dinas Kesehatan & 2 & 5 \\
\hline
\end{tabular}




\begin{tabular}{|c|l|c|c|}
\hline 9. & $\begin{array}{l}\text { Dinas Perindustrian dan Pe } \\
\text { rdagangan }\end{array}$ & 1 & 6 \\
\hline 10. & $\begin{array}{l}\text { Dinas Kelautan dan Perika } \\
\text { nan }\end{array}$ & 3 & 3 \\
\hline 11. & $\begin{array}{l}\text { Dinas Kependudukan dan } \\
\text { Catatan Sipil }\end{array}$ & 3 & 4 \\
\hline
\end{tabular}

Sumber: Data yang diolah, 2017

\section{Hasil Penelitian}

Analisis yang digunakan dalam penelitian ini analisis diskriptif dan analisis regresi linear berganda

Tabel 2

Karakteristik Responden Berdasarkan Jenis Kelamin

\begin{tabular}{|l|c|c|c|}
\hline Karakteristik & Kategori & Jumlah & Presentase \\
\hline \multirow{3}{*}{ Jenis kelamin } & Pria & 40 & $58,53 \%$ \\
\cline { 2 - 4 } & Wanita & 28 & $41,17 \%$ \\
\cline { 2 - 4 } & Total & 68 & $100 \%$ \\
\hline
\end{tabular}

Sumber: Data yang diolah, 2017

Hasil distribusi jenis kelamin dari 68 responden diketahui bahwa 58,53\% atau 40 orang responden berjenis kelamin laki-laki, dan $41,17 \%$ atau 28 orang responden berjenis kelamin perempuan.

Tabel 3

Karakteristik Responden Berdasarkan Umur

\begin{tabular}{|c|c|c|c|}
\hline \multirow{3}{*}{ Karakteristik } & Kategori & Jumlah & Presentase \\
\hline \multirow{4}{*}{ Umur } & $20-29$ & 13 & $19,11 \%$ \\
\cline { 2 - 4 } & $30-39$ & 18 & $26,47 \%$ \\
\cline { 2 - 4 } & $40-49$ & 18 & $26,47 \%$ \\
\cline { 2 - 4 } & $50-59$ & 19 & $27,95 \%$ \\
\cline { 2 - 4 } & Total & 68 & $100 \%$ \\
\hline
\end{tabular}

Sumber: data yang diolah, 2017

Hasil distribusi umur dari 68 responden diketahui bahwa umur 20-29 dengan presentase $19,11 \%$ berjumlah 13 orang, umur30-39 dengan presentase 26,47\% berjumlah 18 orang, umur 40-49 dengan presentase $26,47 \%$ berjumlah 18 orang, umur 50-59 dengan presentase $27,94 \%$ berjumlah 19 orang.

Tabel 5

Karakteristik Responden Berdasarkan Pendidikan

\begin{tabular}{|l|c|c|c|}
\hline \multicolumn{1}{|c|}{ A. Karakteristik } & Kategori & Jumlah & Presentase \\
\hline Pendidikan & SMA & 26 & $38,24 \%$ \\
\hline
\end{tabular}




\begin{tabular}{|c|c|c|c|}
\hline \multirow{4}{*}{} & D3 & 10 & $14,70 \%$ \\
\cline { 2 - 4 } & S1 & 25 & $36,77 \%$ \\
\cline { 2 - 4 } & S2 & 7 & $10,29 \%$ \\
\cline { 2 - 4 } & Total & 68 & $100 \%$ \\
\hline
\end{tabular}

Sumber: data yang diolah, 2017

Hasil distribusi pendidikan terakhir dari 68 responden diketahui bahwa 38,24\% atau 26 orang responden berpendidikan SLTA, SMK dan SMEA, 14,70\% atau 10 orang responden berpendidikan D3 jurusan Administrasi Negara, Akuntansi, Teknik Sipil, Informatika, Gizi, 36,77\% atau 25 orang responden berpendidikan S1 jurusan Pertanian, Peternakan, Akuntansi, Teknik Sipil, Teknik Informatika, Ekonomi Pembangunan, Ilmu Kelautan, Pendidikan, Kesehatan dll, dan 10,29\% atau 7 orang responden berpendidikan S2 jurusan Teknik Sipil, Magister Manajemen, Pertanian, Administrasi Publik.

Hasil Uji Regresi Linear Berganda

Tabel dibawah ini menunjukan bahwa diperoleh model persamaan regresi linear berganda sebagai berikut:

$$
\begin{aligned}
& \mathrm{Y}\left.=13,466+1,102 \mathrm{X}_{1}+0,288 \mathrm{X}_{2}+1,343 \mathrm{X}_{3}+0,180 \mathrm{X}_{4}-0,554\right) \mathrm{X}_{5}+\varepsilon \\
& \mathrm{Y}=\text { Kualitas Informasi Akuntansi } \\
& 13,466=\text { Konstanta } \\
& \mathrm{X} 1 \quad=\text { Informasi yang relevan } \\
& \mathrm{X} 2 \quad=\text { Informasi yang terpercaya } \\
& \mathrm{X} 3 \quad=\text { Informasi yang lengkap } \\
& \mathrm{X} 4 \quad=\text { Informasi yang tepat waktu } \\
& \mathrm{X} 5 \quad=\text { Informasi yang dimengerti } \\
& \varepsilon \quad=\text { Error }
\end{aligned}
$$

\begin{tabular}{|c|c|c|c|c|c|}
\hline \multirow{2}{*}{$\begin{array}{l}\text { Variabel } \\
\text { Independen }\end{array}$} & \multicolumn{2}{|c|}{$\begin{array}{l}\text { Unstandardized } \\
\text { Coefficient }\end{array}$} & \multirow{2}{*}{ t hitung } & \multirow{2}{*}{ Sig } & \multirow{2}{*}{ Keterangan } \\
\hline & B & $\begin{array}{l}\text { Std. } \\
\text { Error }\end{array}$ & & & \\
\hline $\begin{array}{l}\text { Konstanta } \\
\text { (Constant) }\end{array}$ & 13,446 & 5,244 & 2,574 & 0,012 & Signifkan \\
\hline Relevan (X1) & 1,102 & 0,260 & 3,889 & 0,000 & Signifikan \\
\hline Terpercaya (X2) & 0,288 & 0,284 & 1,103 & 0,315 & $\begin{array}{l}\text { Tidak } \\
\text { Signifikan }\end{array}$ \\
\hline Lengkap (X3) & 1,343 & 0,302 & 4,448 & 0,000 & Signifikan \\
\hline $\begin{array}{l}\text { Tepat Waktu } \\
\text { (X4) }\end{array}$ & 0,554 & 0,298 & 0,864 & 0,574 & $\begin{array}{l}\text { Tidak } \\
\text { Signifikan }\end{array}$ \\
\hline Dimengerti (X5) & $-0,554$ & 0,298 & $-1,854$ & 0,068 & $\begin{array}{l}\text { Tidak } \\
\text { Signifikan }\end{array}$ \\
\hline
\end{tabular}

Tabel 5 Hasil Uji Analisis Regresi Linear Berganda

Sumber: data yang diolah, 2017 
a. Hasil Uji t (Parsial)

1. Informasi yang relevan menunjukan hasil t sebesar 3,889 dengan demikian dapat disimpulkan bahwa secara parsial informasi yang relevan berpengaruh positif terhadap kualitas informasi akuntansi. Terdapat nilai sig sebesar 0,000 . Nilai signifikasi tersebut lebih besar dari nilai probabilitas yaitu 0,05 atau nilai $0,000<0,5$ maka dapat bahwa H1: Pengaruh informasi yang relevan terhadap kualitas informasi akuntansiterdukung.

2. Informasi yang terpercaya menunjukan hasil $\mathrm{t}$ sebesar 1,103 dengan demikian dapat disimpulkan bahwa secara parsial informasi yang terpercaya tidak berpengaruh positif terhadap kualitas informasi akuntansi. Terlihat pada tabel 8 memiliki nilai signifikasi sebesar 0,315 . Nilai signifikasi tersebut lebih besar dari nilai probabilitas yaitu 0,05 atau nilai $0,315>0,05$, maka dapat disimpulkan bahwa $\mathrm{H} 2$ : pengaruh informasi yang tepat waktu terhadap kualtas informasi akuntansi tidak terdukung.

3. Informasi yang lengkap menunjukan hasil t sebesar 4,448 dengan demikian dapat disimpulkan bahwa secara parsial Informasi yang lengkap berpengaruh positif terhadap kualitas informasi akuntansi. Terlihat pada tabel memiliki nilai signifikasi sebesar 0,000. Nilai signifikasi tersebut lebih kecil dari nilai probabilitas yaitu 0,05 atau nilai $0,000<0,05$, maka dapat disimpulkan bahwa H3: Pengaruh informasi yang lengkap terhadap kualitas informasi akuntansiterdukung.

4. Informasi yang tepat waktu menunjukan hasil $\mathrm{t}$ sebesar 0,565 dengan demikian dapat disimpulkan bahwa secara parsial informasi yang tepat waktu berpengaruh positif terhadap kualitas informasi akuntansi. Terlihat pada tabel memiliki nilai signifikasi sebesar 0,574. Nilai signifikasi tersebut lebih besar dari nilai probabilitas yaitu 0,05 atau nilai $0,574>0,05$, maka dapat disimpulkan bahwa H4: pengaruh informasi yang tepat waktu terhadap kualitas informasi akuntansitidak terdukung.

5. Informasi yang dimengerti menunjukan hasil t sebesar $-1,857$ dengan demikian dapat disimpulkan bahwa secara parsial informasi yang dimengerti tidak berpengaruh positif terhadap kualitas informasi akuntansi. Terlihat pada tabel memiliki nilai signifikasi sebesar 0,680. Nilai signifikasi tersebut lebih besar dari nilai probabilitas yaitu 0,05 atau nilai $0,680>0,05$, maka dapat disimpulkan bahwa H5: informasi yang lengkap berpengaruh terhadap kualitas informasi akuntansitidak terdukung.

b. Hasil Uji F

Uji F (simultan digunakan untuk mengukur pengaruh variabel independen terhadap variabel dependen secara bersama-sama. 
Tabel 6. Hasil Uji F (Simultan)

\begin{tabular}{|c|c|c|c|}
\hline Model & $\begin{array}{c}\text { Sum of Square } \\
\mathrm{S}\end{array}$ & \multirow{2}{*}{$\mathrm{F}_{\text {hitung }}$} & Sign. \\
\hline Regression & 1637,198 & & \multirow{2}{*}{28,140} \\
Residual & 721,434 & 0,000 \\
\hline Total & 2358,632 & & \\
\hline
\end{tabular}

Sumber: Data yang diolah, 2017

Berdasarkan hasil uji $\mathrm{F}$ diperoleh nilai $\mathrm{F}$ sebesar 28,140 dengan nilai signifikasi 0, 000. Nilai signifikasi 0,000 menunjukan bahwa H0 ditolak dan Ha didukung kare na nilai $0,000<0,05$. Artinya informasi relevan, terpercaya, lengkap, tepat waktu dan dimengerti bersama-sama berpengaruh secara signifikan terhadap kualitas inf ormasi akuntansi.

\section{c. Hasil Uji Koefisien Determinasi $\left(\mathrm{R}^{2}\right)$}

Koefisien Determinasi dengan menunjukan besarnya variabel independen informasi yang relevan, terpercaya, lengkap, tepat waktu, dan dimengerti secara serentak berpengaruh terhadap variabel dependen kualitas informasi akuntansi. Hasil pengujian koefisien determinasi ditunjukan pada tabel 9 dibawah ini:

Tabel 10. Hasil Uji R Square

\begin{tabular}{|l|l|l|l|l|}
\hline Model & $\mathrm{R}$ & R Square & $\begin{array}{l}\text { Adjusted R } \\
\text { Square }\end{array}$ & $\begin{array}{l}\text { Std. Error } \\
\text { of Estimate }\end{array}$ \\
\hline 1 & 0,833 & 0,694 & 0,669 & 3,441 \\
\hline
\end{tabular}

Pada tabel 10 nilai R Square menunjukan angka 0,669. Hal ini mengindikasikan bahwa kontribusi variabel informasi yang relevan, terpercaya, lengkap, tepat waktu dan dapat dimengerti terhadap variabel kualitas informasi akuntansi adalah sebesar $66,9 \%$. 
PEMBAHASAN

\section{Pengaruh informasi yang relevan terhadap kualitas informasi akuntansi.}

Hasil pengujian hipotesis 1 yaitu informasi yang relevan secara parsial berpengaruh terhadap kualitas informasi akuntansi. Hasil pengujian statistik menunjukan bahwa informasi yang relevan dengan tingkat signifikasi $0,000<0,05$. Hasil analisis ini menunjukan bahwa 11 Instansi Organisasi Perangkat Daerah (OPD) telah memberikan informasi yang relevan.

Hasil penelitian ini mendukung penelitian yang dilakukan oleh Rusnanto (2016) bahwa informasi yang relevan berpengaruh signifikan terhadap kualitas informasi akuntansi pada rumah sakit. Informasi dikatakan relevan apabila memiliki manfaat, menambah pengetahuan atau nilai bagi parapengambil keputusan, untuk mengurangi ketidakpastian (Aditya, 2014).

\section{Pengaruh informasi yang terpercaya terhadap kualitas informasi akuntansi.}

Hasil pengujian hipotesis 2 yaitu informasi yang terpercaya secara parsial tidak berpengaruh terhadap kualitas informasi akuntansi. Hasil pengujian statistik menunjukan bahwa informasi yang terpercaya dengan tingkat signifikasi $\quad 0,351<0,05$. Hasil analisis ini menunjukan bahwa 11 Instansi Organisasi Perangkat Daerah (OPD) belum memberikan informasi yang terpercaya. Perlu diperhatikan agar Informasi akuntansi pada 11 Instansi tidak bergantung pada keinginan pada keinginan pihak tertentu.

Hasil penelitian ini tidak mendukung penelitian yang dilakukan oleh Aditya (2014) bahwa terpercaya berpengaruh positif terhadap kualitas informasi akuntansi pada rumah sakit. Informasi yang terpercaya harus terbebas dari kesalahan dan bias serta akurat menjelaskan kejadian atau aktivitas (Romney dalam Windarsono, 2007). Informasi yang terpercaya harus bias di pertanggungjawabkan dan diperoleh dengan cara yang benar dan didistribusikan dengan cara yang benar.

\section{Pengaruh informasi yang lengkap terhadap kualitas informasi akuntansi.}

Hasil pengujian hipotesis 3 yaitu informasi yang lengkap secara parsial berpengaruh terhadap kualitas informasi akuntansi. Hasil pengujian statistik menunjukan bahwa lengkap dengan tingkat signifikasi $0,000<0,05$. Hasil analisis ini menunjukan bahwa 11 Instansi Organisasi Perangkat Daerah (OPD) telah memberikan informasi yang lengkap, memuat aspekaspek penting yang melatarbelakangi setiap butir informasi utama yang termuat.

Hasil penelitian ini mendukung penelitian yang dilakukan oleh Rusnanto (2016) bahwa informasi yang lengkap berpengaruh signifikan terhadap kualitas informasi akuntansi pada rumah sakit. 


\section{Pengaruh informasi yang tepat waktu terhadap kualitas informasi akuntansi.}

Hasil pengujian hipotesis 4 yaitu informasi yang tepat waktu secara parsial tidak berpengaruh terhadap kualitas informasi akuntansi. Hasil pengujian statistik menunjukan bahwa informasi yang tepat waktu dengan tingkat signifikasi $0,574>0,05$. Hasil analisis ini menunjukan bahwa 11 Instansi Organisasi Perangkat Daerah (OPD) belum memberikan informasi yang tepat waktu, ini di tujukan pada indikator pembaharuan informasi dan sistematis dan keteraturan waktu penyampaian informasi reponden menjawab netral.

\section{Hasil penelitian ini tidak mendukung penelitian yang dilakukan oleh Windarsono (2004) bahwa informasi yang tepat waktu berpengaruh terhadap kualitas informasi manajemen. Informasi harus disampaikan secepat mungkin pada saat pengambilan keputusan agar dapat membantu pengambilan keputusan dan tertundanya pengambiilan keputusan. Informasi juga harus terbebas dari kesalahan yang material (Aditya, 2014) \\ Pengaruh informasi yang dimengerti terhadap kualitas informasi akuntansi.}

Hasil pengujian hipotesis 5 yaitu informasi yang dimengerti secara parsial berpengaruh terhadap kualitas informasi akuntansi. Hasil pengujian statistik menunjukan bahwa informasi yang dimengerti dengan tingkat signifikasi 0,680>0,05. Hasil analisis ini menunjukan bahwa 11 Instansi Organisasi Perangkat
Daerah (OPD) belum memberikan informasi yang mudah dimengerti, sesuai dengan batas pemahaman, bentuk dan istilah yang disesuaikan bagi penggunanya. Apabila pihak instansi memberikan informasi yang dapat dimengerti akan memberikan pengaruh postif terhadap kualitas informasi akuntansi.

Hasil penelitian ini tidak mendukung penelitian yang dilakukan oleh Rusnanto (2014) bahwa informasi yang dimengerti berpengaruh signifikan terhadap kualitas informasi akuntansi pada rumah sakit.

Pengaruh informasi yang relevan, terpercaya, lengkap, tepat waktu, dan dimengerti berpengaruh secara simultan terhadap kualitas informasi akuntansi.

Hasil pengujian hipotesis 6 yaitu pengaruh informasi yang relevan, terpercaya, lengkap, tepat waktu, dan dimengerti berpengaruh secara simultan terhadap kualitas informasi akuntansi. Hasil pengujian statistik menunjukan bahwa informasi yang informasi yang relevan, terpercaya, lengkap, tepat waktu, dan dimengerti dengan tingkat signifikasi $0,000<0,05$. Hasil analisis ini menunjukan bahwa 11 Instansi Organisasi Perangkat Daerah (OPD) telah memberikan informasi yang relevan, terpercaya, lengkap, tepat waktu dan dimengerti.

Hasil penelitian ini
mendukung penelitian Aditya
$(2014)$ bahwa informasi yang
relevan, terpercaya, lengkap, tepat
waktu dan dimengerti berpengaruh
simultan terhadap kualitas
informasi akuntansi. Romney
(2006) menjelaskan bahwa ada


beberapa faktor kualitas informasi akuntansi yaitu relevant, reliable, complete, timely, dan understandable.

\section{Kesimpulan}

Penelitian ini bertujuan untuk menguji faktor- faktor yang mempengaruhi kualitas informasi akuntansi. Faktor- faktor kualitas informasi akuntansi yaitu, informasi yang relevan, terpercaya, lengkap, tepat waktu dan dimengerti. Berdasarkan hasil analisis data, pengujian hipotesis, dan pembahasan maka dapat ditarik kesimpulan dari penelitian ini sebagai berikut:

a. Pengujian secara parsial dengan nilai signifikasi $5 \%$ informasi yang relevan dan lengkap berpengaruh terhadap kualitas informasi akuntansi. Sedangkan informasi yang terpercaya, tepat waktu dan dimengerti tidak berpengaruh terhadap kualitas informasi akuntansi.

b. Pengujian secara simultan dengan nilai signifikasi $5 \%$ informasi yang relevan, terpercaya, lengkap, tepat waktu dan dimengerti berpengaruh terhadap kualitas informasi akuntansi.

c. Berdasarkan uji koefisien determinasi (R2) dibuktikan bahwa informasi yang relevan, terpercaya, lengkap, tepat waktu dan dimengerti terhadap variabel kualitas informasi akuntansi $66,9 \%$ sedangkan $33,1 \%$ dipengaruhi oleh faktor lain diluar pembahasan ini.

\section{Implikasi}

Hasil penelitian ini mempunyai beberapa implikasi bagi berbagai pihak yang terkait dengan kualitas informasi akuntansi antara lain:

Bagi penulis, memberikan bukti empiris mengenai faktor- faktor yang mempengaruhi kualitas informasi akuntansi. Selain itu sebagai sarana menerapkan dan mempraktekkan ilmu pengetahuan khsusnya pada Informasi Akuntansi pada Organisasi Perangkat Daerah (OPD) Kabupaten Gunungkidul secara langsung.

Bagi Instansi, untuk menunjang pekerjaan setiap karyawan sehingga Instansi dapat menerapkan informasi akuntansi yang tepat dan dapat dimanfaatkan secara maksimal oleh pemakai informasi akuntansi.

Bagi peneliti lain, dapat dijadikan bahan refrensi untuk penelitian selanjutnya. Penelitian ini diharapkan dapat memperluas wawasan pengetahuan.

\section{Saran}

Berdasarkan kesimpulan dan implikasi yang ada dalam penelitian, maka dapat dikemukakan beberapa saran yang dapat dijadikan pertimbangan untuk penelitian selanjutnya, yaitu:

a. Perlunya memperluas obyek penelitian, tidak hanya 11 Instansi saja sehingga lebih dapat dijadikan acuan bagi kepentingan generalisasi permasalahan.

b. Bagi penelitian selanjutnya, diharapkan tidak terbatas pada penyebaran kuesioner saja. Perlu ditambahkan metode wawancara, untuk menghindari kemungkinan bias atau tidak obyektif dari responden dalam pengisian kuesioner. 


\section{DAFTAR PUSTAKA}

Aditya, S. A. 2014. "Analisis

Faktor-faktor Yang Mempengaruhi

Kualitas Informasi Akuntansi Pada

RSUD Ungaran. Jurnal Akuntansi.

Universitas Dian Nuswantoro.

Semarang.

Fridayani, Devani. 2012.

"Pengaruh Kompetensi dan

Pertimbagan Profesional Auditor

Internal Terhadap Kualitas Bukti

Audit yang Dikumpulkan (Studi

Kasus Pada BUMN yang Berpusat

di Bandung". Universitas

Pendidikan Indonesia.

Ghozali, Imam. 2013. "Aplikasi

Analisis Multivariate dengan

SPSS". Semarang:BP Universitas

Diponegoro.

Indriani, R dan Khoriyah, W.

2010. "Pengaruh Kualitas

Pelaporan Keuangan Terhadap

Informasi Asimetri”. Jurnal SNA

XIII. Purwokerto.

Jogiyanto, HM. 1999. "Analisis

dan Desain Sistem Informasi :

Pendekatan Terstruktur Teori dan

Praktek Aplikasi Bisnis". ANDI

Yogyakarta:

Yogyakarta. 2003. " Sistem

Informasi Berbasis Komputer:

Konsep Dasar dan Komponen.

Edisi 2.Yogyakarta :

BPFE.Yogyakarta.

Kadir, Abdul. 2003. "Pengenalan

Sistem Informasi”. Andi Offset:

Yogyakarta.

Mulyanto, Agus. 2009. "Sistem

Informasi Konsep dan Aplikasi".

Pustaka Pelajar: Yogyakarta.

Republik Indonesia. 2016.

Peraturan Pemerintah No. 18
Tahun 2016 Tentang Perangkat

Daerah.

2015.

Undang- Undang No. 9 Tahun

2015 Tentang Pemerintah Daerah.

Undang- Undang No. 17 Tahun

2003 Tentang Keuangan Negara.

Romney B. Marshall. 2006.

"Accounting Information System".

Salemba Empat: Jakarta.

Rusnanto, Galeh. 2016. “Analisis

Faktor- faktor Yang Mempengaruhi

Kualitas Informasi Akuntansi

(Studi Empiris Pada Rumah Sakit

eks- Karisidenan Surakarta)".

Jurnal Ekonomi dan Bisnis.

Universitas Muhammadiyah

Surakarta. Surakarta.

Sugiyono. 2016. "Metode

Penelitian Pendidikan (Pendekatan

Kuantitatif, Kualitatif, R\&D)".

Alfabeta: Bandung.

Windarsono, Agus. 2007.

"Pengaruh Kualitas Informasi

Manajemen Terhadap Kinerja

Manajerial". Hal: 286-299. Vol. 2,

No. 2. Jurnal Akuntansi.

Universitas Pendidikan Indonesia.

Bandung. 